Word count: 6,733 (6,865 including abstract and key words)

\title{
A Clash of Internationalisations: New Zealand and the Bologna Process
}

\section{Abstract}

In this paper we examine the normative and strategic impact of the Bologna Process on the New Zealand University system. We argue that, from a normative perspective, Bologna has not resulted in substantive change. Nevertheless, a specific, if low-level, normative response has been evident, driven by perceived market incentives and the market-based norms that underpin higher education and internationalisation strategies in the New Zealand context. We contend that this response necessitates a conceptual extension of the normative power framework. From a strategic perspective, we consider the extent to which Bologna has succeeded in making Europe a geographic focus in New Zealand University internationalisation strategies. In this respect, we find strategic priorities lie elsewhere, again reflecting the competitive market-based norms that underpin higher education in New Zealand.

Key Words: Bologna Process; European Union; New Zealand; Normative Power; Compliance Confirmation; Higher Education; Internationalisation

\section{Introduction}

In this article, we examine both the normative and strategic impact of the Bologna Process in New Zealand. From a normative perspective, we consider the extent to which the Bologna Process has prompted domestic reform beyond European borders, utilising the framework of Normative Power Europe. The aim is not to enter the debate as to whether the European Union (EU) is a normative power, nor is it to consider the extent to which the EU's involvement in the Bologna Process represents an attempt to assert normative power. Rather, the aim is to examine the extent to which the norms contained within the Bologna Process 
have spread beyond the borders of the European Higher Education Area (EHEA), focussing on the case of New Zealand. In this respect, we find no evidence of substantive change, but this is not to say that a normative impact has been entirely absent. Evident is a specific, if low-level, response driven by the competitive market-based norms that underpin the internationalisation strategies of New Zealand universities. This response challenges existing frameworks for understanding Normative Power Europe, requiring some conceptual extension in order to adequately address the New Zealand case.

From a strategic perspective, we are interested in the extent to which the Bologna Process has met its goal of increasing the international attractiveness of the European system of higher education, using New Zealand as a case study. This objective has been central to the Bologna Process from the very beginning. The Sorbonne Declaration (1998) stated that "the international recognition and attractive potential of our systems are directly related to their external and internal readabilities.” One year later, the Bologna Declaration (1999) included "the objective of increasing the international competitiveness of the European system of higher education," adding that "we need to ensure that the European higher education system acquires a world-wide degree of attraction equal to our extraordinary cultural and scientific traditions.” This goal has been further elaborated upon in subsequent Ministerial Communiqués, including the Bergen Communiqué $(2005,4)$ which noted that “the European Higher Education Area must be open and should be attractive to other parts of the world.” It went on to state that "we see the European Higher Education Area as a partner of higher education systems in other regions of the world, stimulating balanced student and staff exchange and cooperation between higher education institutions” (5). In light of these objectives, we examine the strategic importance attached to Europe by universities in New Zealand, finding that university internationalisation strategies rooted in a competitive marketbased higher education system have in practice resulted in a different geographic focus. 
The paper is based on an analysis of key policy documents and a survey completed by New Zealand university representatives guided by the analytic interests discussed above. The policy documents include reports, papers and communications within which the Bologna Process is the focus, or referenced. The survey was designed to get an insight into the internationalisation strategies of universities in New Zealand, including their priorities and drivers. The survey asked respondents to identify, inter alia, the priorities guiding internationalisation at their institution, reasons underpinning the internationalisation process, and key external drivers of internationalisation, as well as identifying and ranking (by region and state) the geographic foci of their internationalisation strategy. Moreover, it asked specifically about key European initiatives, namely the Bologna Process and the EHEA, the European Credit Transfer and Accumulation System (ECTS), the Bologna Diploma Supplement, the Lisbon Recognition Convention, Erasmus+ and Horizon2020. Respondents were asked whether they were aware of each of these initiatives and whether they play any role in the internationalisation strategies of their institution. The survey was directed to the person with strategic oversight of internationalisation at each university, but they were encouraged to consult with other colleagues as appropriate. The survey was distributed electronically to all eight New Zealand universities, with respondents also being given alternative feedback mechanisms (e.g. face-to-face engagement) should these be preferred. A response rate of 50 per cent was achieved.

Before presenting our findings, we discuss the concept of normative power and the nature of internationalisation in the New Zealand context. These two contextual sections provide necessary background information for addressing the normative influence of the Bologna Process in New Zealand, while the latter is important for understanding the level of strategic importance attached to Europe by New Zealand universities. 


\section{Normative Power}

The concept of normative power, stemming from Manners (2002) seminal article, was an attempt to move beyond the civilian-military dichotomy that had to that point dominated debate on the European Union's international role. It was framed as a supplement both to Duchêne’s conception of a civilian organisation “long on economic power” (Duchêne 1973, 19), and to Bull’s “need for military power” (Bull 1982, 19), arguing that EU influence need not necessarily be built on such a material foundation. In so doing, it rests on three fundamental claims: (i) that new forms of agency are replacing, or at least joining, sovereign states as actors in the international system; (ii) that universal principles of peace and justice increasingly define the international space within which actors operate; and (iii) that the European Union embodies these transformations which are in turn at the core of its identity as an international actor (Aggestam 2009, 29).

For Manners, the concept of normative power recognised European influence in the realm of ideas, of 'power over opinion', of 'ideological force': the EU as ideational power. According to this conception, it is the centrality of its core norms that defines the Union as an actor: "the most important factor shaping the international role of the EU is not what it does or what it says, but what it is” (Manners 2002, 252). At a basic level, therefore, norms occupy two places: (i) as a value to be transmitted to other actors and to be diffused throughout the international system - Manners' (239) “idée force” or "ability to shape conceptions of 'normal' in international relations"; and (ii) as a framework guiding the Union's external relations - as the Treaty on European Union asserts, “[t]he Union's action on the international scene shall be guided by the principles which have inspired its own creation, development and enlargement, and which it seeks to advance in the wider world” (European Union 2012, art.21). Normative power, in other words, may be embodied both in 'presence' and in 'action', or as Gerrits (2009, 4) alternatively suggests, by ‘default' and by ‘design’. 
Clearly, this conception of normative power raises a number of important questions. First, while as noted normative power is an attempt to move beyond debates dominated by discussions of empirical strength in international relations, as embodied in statist conceptions of actorness, must normative power necessarily be divorced from such a material foundation? For Aggestam $(2009,29)$ this is definitively the case: "the central aim of NPE", she asserts, "is about the power of ideas themselves. Their attraction should be seen as independent from any link to material incentives”. In her view, resiling from this position would fundamentally undermine the distinctiveness of the concept of Normative Power Europe. By contrast, Manners' (2002, 239) initial formulation saw normative power as augmenting rather than replacing other conceptions of power, suggesting even at the outset that this distinction was not to be so strongly drawn. This is a position that has strengthened in Manners' conceptualisation, with subsequent acknowledgement being made that "economic incentives or military capabilities may underpin normative power” (Diez and Manners 2007, 176). In such a view, for example, it is reasonable to suggest that the attractiveness of the Union's economic norms would be related to its perceived economic strength/success.

Second, how is the influence of normative power, be it active or passive, to be conceptualised? How are norms spread? Manners (2002, 242-245) addresses this directly, identifying six mechanisms of norm diffusion: contagion, informational, procedural, transference, overt, and the cultural filter. These may be roughly categorised as direct (informational, procedural, transference, overt) and indirect (contagion, cultural filter) mechanisms of norm diffusion. Notwithstanding its centrality to the conceptualisation of normative power, however, this framework is insufficient to the task of this article in examining New Zealand as a receiver (or not) of Bologna norms, focused as it is on the European Union and its role as norm-sender. Since Manners’ initial formulation, however, significant literature on norm diffusion has emerged, examining the manner in which "ideas, 
normative standards, or... policies and institutions spread across time and space” (Börzel and Risse 2012, 5). In this we can find a range of elements that intersect with, and provide further nuance to, the mechanisms outlined above and which help to explain the normative impact of the Bologna Process in New Zealand. This is particularly the case in relation to indirect diffusion. Where Manners highlights in broad brush strokes the way in which third parties adopt norms through a process of 'contagion', ${ }^{1}$ Börzel and Risse further unpack such normative emulation, pointing to three distinct mechanisms. Competition involves the adoption of best practice in the context of rivalry with other actors, for example to promote economic growth (9). Lesson drawing involves the adoption of norms in the context of problem solving, with the transference of norms into the domestic context that are perceived elsewhere to have solved a problem currently being faced (9-10). Normative emulation is premised on the desire to be a "member[] of the international community 'in good standing"” (10), with the adoption of particular norms (e.g. on human rights, the rule of law) seen as serving a legitimising function in this respect. Finally, mimicry is a more passive process of downloading norms, policies or institutions because these are in essence appropriate - they are "what everybody does in a given community" (10). Where competition and lesson drawing essentially stem from an analysis made by actors as to the functional value of norms, policies and institutions, normative emulation and mimicry are related more to the perceived legitimacy of the norm sender - in this case the European Union (see e.g. Jetschke and Murray 2012, 181).

The final question that can be raised in relation to the concept of normative power relates to outcome: in identifying the expression of normative power, must there be a transformative impact? As Birchfield $(2011,144)$ notes, "the extent to which the EU has been able to project power and influence and diffuse its norms is one test by which scholars are

\footnotetext{
${ }^{1}$ Contagion involves the unintended projection of norms when third parties seek to replicate the EU's 'virtuous example'
} 
able to demonstrate the conceptual and theoretical advantages of the NPE concept", suggesting therefore the significance of outcome. And indeed for Manners (2008, 47), Normative Power Europe is to be judged "in terms of its principles, actions and impact", a tripartite formulation in which consideration of the "impact and outcomes of EU actions" (58) is central. Importantly, however, the impact of norm diffusion is again varied. In this respect, Risse $(2015,5)$ recognises three potential outcomes. Adoption/convergence involves the wholesale importing of normative structures. By contrast, adaptation/transformation recognises that localisation processes may also be at play, adapting structures to domestic circumstances. Finally, resistance posits rejection of normative influences a third potential outcome of norm diffusion. As will become clear, however, these categories are not sufficient to the task of explaining the normative impact of the Bologna process in the New Zealand case, with a conceptual extension - compliance confirmation - being posited in this article as a way to frame an evident, if low-level, response.

\section{Internationalisation in the New Zealand Context: The Marketisation of Education}

The single most significant factor in the internationalisation strategies of New Zealand universities today was the rapid transformation of New Zealand's economy to neoliberal market orthodoxy that took place from the mid-1980s. When the fourth Labour Government was elected in 1984, it was confronted with a fiscal deficit and debt crisis. Under the prior National Government (1975-1984), and following the oil crisis of 1973-1974, a Keynesian policy of significant external borrowing to boost economic growth and employment through funding domestic infrastructure investments (primarily around energy generation and the conversion of main trunk rail lines to electricity) meant a quadrupling of official public debt. Over the lifetime of the National Government, net official public debt increased from 4.4 per cent of GDP to 29.6 per cent, with an increase in interest from 2.5 per cent to 11.5 per cent of 
tax receipts (Wilkinson 2017: 5). This was accompanied by an increasing fiscal deficit, which by 1984 was approaching 7 per cent of GDP (Evans et al. 1996, 1860; Wilkinson 2017, 6).

When the Labour Government assumed office on 26 July 1984 it launched a process of economic restructuring that saw it "abandon[] its traditional constituencies and orthodoxies and pursue[] a rigorous policy of economic liberalism and deregulation” (Pratt and Clark 2005, 308). Through a mechanism of 'crash through or crash', a process of neoliberal restructuring took place of such a scale and at such a pace not seen elsewhere in the developed world. Deregulation, liberalisation and privatisation were at the core of a these reforms, with the market, competition and individual responsibility becoming central to the functioning of economy and society. Neoliberal orthodoxy in effect came to penetrate almost every aspect of state, economy and society, including the university sector.

The debate on tertiary education policy took place from the end of the 1980s, centring on the extent to which universities should be subject to market disciplines, and involving discussion as to whether a university education was a private benefit or a public good. While the New Zealand Vice Chancellors' Committee fell on the public good side of the equation, seeing education as a right and advocating maintenance of public funding as far as was possible (Universities Review Committee 1987), organisations such as the New Zealand Business Roundtable fell toward the other end of the spectrum, arguing that as a private good, education should be exposed to the same market framework as other commodities (NZBRT 1988). This latter view clearly reflected the thinking of the New Zealand Treasury, which envisaged government financial intervention as producing sub-optimal outcomes (New Zealand Treasury 1987, 177), advocating the removal of government controls and mechanisms to instead allow universities to operate as profit centres in a contested marketplace (193). In this view, "Information and knowledge are the business of tertiary education" [emphasis added] with the most optimal outcomes produced when "the tertiary 
sector is enabled and given incentives to develop its core business as efficiently as possible” (195). It was in this direction that government policy was increasingly to travel.

The Education Amendment Act 1990 transformed the statutory foundation on which the New Zealand University system had been built. From a system of effective autonomy under individual Acts of Parliament, a single regulatory framework was established involving a move from funding through a semi-independent agency to direct funding from the Ministry of Education, as well as the requirement for corporate charters, CEOs, contractual engagement with the Ministry and other paraphernalia of economic market actors (Kelsey 2000; Olssen 2002). A new funding formula was subsequently introduced, which by 1991 meant that universities were receiving government funding for only 85 per cent of student course costs (Olssen 2002, 66), requiring them to make up the difference through fees. At the same time, international students, with the exception of those receiving scholarships, whose tuition until that point had been heavily subsidised by the government, were required to start paying full cost tuition fees (Smith \& Parata 1997). In the years since, this marketised vision of university education has been strengthened, with greater emphasis on competition among tertiary providers for student dollars and annualised funding cycles based on student demand (characterised also by ongoing declines in the relative level of central government funding). The consequent underfunding of the university sector, the emphasis on universities as competitive market actors, and the vision of education as a commodity accumulated for individual benefit rather than as a right or a public good, provide the context in which New Zealand universities' internationalisation strategies are to be understood. Importantly, with the cost of tuition for domestic students still heavily subsidised by government funding and restrictions placed on the level of fees that institutions can charge to cover the difference, the fees levied upon international students which are not subject to the same restrictions have become an increasingly important mechanism for addressing this funding shortfall. Indeed, 
the Vice-Chancellor of the University of Auckland observed in 2012 that at his institution, “each international student generates on average a margin (in commercial terms, profit) of \$7000 over that generated by an equivalent domestic student” (McCutcheon 2012).

The direct consequence of this policy and legislative evolution is that internationalisation in the New Zealand context has been conceived in largely instrumental terms as a mechanism for overcoming domestic funding deficits. This stands in stark contrast to visions of internationalisation focusing on more cosmopolitan values such as intercultural communication, and on the enhancement of educational and research quality. In this latter respect, for example, De Wit and Hunter (2015, 3), revising Knight’s (2003) approach, define internationalisation as "the intentional process of integrating an international, intercultural or global dimension into the purpose, functions and delivery of post-secondary education, in order to enhance the quality of education and research for all students and staff, and to make a meaningful contribution to society.”

This instrumental trend has long been evident in the New Zealand tertiary sector. In a 2006 study commissioned by the Ministry of Education, for example, it was noted that institutional strategies have been dominated by a focus on education exports (McInnes et al. 2006, 11), with increased revenue and funding identified as the primary benefit of internationalisation for tertiary institutions (70). More than a decade later this pattern remains. In our survey, when asked to rank their five greatest priorities in relation to the various aspects of internationalisation taking place at their institution, three out of four respondents ranked expanding the recruitment of international undergraduate and taughtpostgraduate students first; the other ranked it second. When asked to rank the five most compelling reasons for promoting internationalisation at their university, revenue generation was the only element of internationalisation emphasised by all respondents. Alongside this, three of the four universities highlighted the role of internationalisation in increasing their 
institution's global profile, which itself may be seen as significant in terms of revenue generation through the attraction of foreign students, while one additionally highlighted trade in education services. Reinforcing this, the identified external drivers of internationalisation among survey respondents heavily focused on issues of funding. Three universities underlined the lack of public funding for tertiary education as a key driver: for two it was ranked as the primary driver and for the other it was ranked second only behind international rankings. For New Zealand universities, therefore, stemming from the neoliberal transformation undertaken from the mid-1980s, internationalisation is intrinsically linked with revenue generation through competitive engagement in the market for international education services.

Not surprisingly, economic rationales also sit at the heart of the government view of internationalisation. The New Zealand Leadership Statement for International Education 2011 states that "the level of Government funding for secondary and tertiary education will continue to be under pressure from broader fiscal demands... Our providers should see international education as providing important opportunities for them to generate additional revenues on an ongoing basis” (New Zealand Government 2011, 6). It also focuses on wider economic benefits, including the contribution that foreign students studying in New Zealand make to the national GDP, not only through the payment of tuition fees, but wider expenditure while in New Zealand. In this context, the Leadership Statement set the goal of doubling the contribution of foreign students across all education sectors from primary school to university over the next 15 years to NZ\$5 billion (New Zealand Government 2011, 7). Less than five years later, it was calculated that New Zealand was nearing this target with the total valued at NZ\$4.28 billion in 2015/16, placing education as New Zealand's fourth largest export earner behind only dairy, tourism and meat (Education New Zealand 2017). Other objectives cited are also linked to the mission of economic growth, including encouraging 
"the immigration of highly skilled people” (New Zealand Government 2011, 2), as well as facilitating people-to-people links and improved cultural and linguistic literacy amongst New Zealand students, or in other words, the knowledge and skills required to improve "the national ability to increase trade and wider economic connections," especially with Asia (New Zealand Government 2011, 5). The Leadership Statement for International Education 2011 has recently been replaced by the New Zealand International Education Strategy 20182030, which still places significant weight on the economic value of international students, but also has a notably broader focus than the previous policy. It notes that international education includes not only international students coming to New Zealand, but "our own people travelling the world to experience a global component in their education" (New Zealand Government 2018, 3). It goes on to list "developing global citizens" as one of the three overarching goals of the policy, alongside "delivering an excellent education and student experience” and "achieving sustainable growth” (9). Notwithstanding these recent expressions of intent, the New Zealand university system remains firmly rooted in a neoliberal market-centred normative context, and it seems unlikely that such formulations will have a substantive impact at the institutional level in the foreseeable future, given the underlying conditions that drive the focus on student recruitment as a tool for generating revenue have not changed.

\section{The Normative Impact of the Bologna Process}

When it comes to the normative impact of the Bologna Process on the New Zealand university sector, evidence of substantive influence is at best limited. Nevertheless, some indicative influences may be identified. The initial response to Bologna was a governmental one: Prompted by industry interest, the Ministry of Education and New Zealand Qualifications Authority (NZQA) undertook to determine New Zealand's compatibility, 
culminating in the publication of a paper in 2008 titled New Zealand and the Bologna Process (New Zealand Ministry of Education and NZQA 2008). While highlighting the importance of engaging with Bologna due to the likelihood of it having "a number of implications for the international acceptance of New Zealand tertiary education awards and options for student mobility” (4), the document is more significant for the way in which Bologna was viewed through the lens of New Zealand's vision of internationalisation, and the importance of the international market in education services that this involves. Thus the Process was viewed as potentially significant for enhancing the reputation of tertiary institutions as providers of "world-class education to both domestic and international students" and as a "useful marketing tool in third countries" (4). With university internationalisation frameworks significantly directed toward the recruitment of fee-paying international students as a way to generate revenue, alongside wider economic benefits, the identification of such potential market value in the Bologna Process is unsurprising. Similarly, the focus of the paper on assessing New Zealand's compatibility with the EHEA was consistent with a market-based internationalisation strategy for which qualification framework conflicts are an important barrier to trade, inhibiting inward student mobility. Conceived in terms of norm transfer, what we see here is intriguing evidence of Börzel and Risse's (2012) competition diffusion, with market incentives driving New Zealand institutions' limited engagement with the Bologna Process. In this respect, the examination of compatibility is to be conceived as a defensive response in the context of a competitive international education market, and entirely consistent with New Zealand universities’ vision of internationalisation.

The 2008 paper concluded that New Zealand was already largely compatible with the Bologna Process, including the three-cycle degree structure and the ECTS. However, it did also identify areas where further work had been initiated to build on this "high level of 
comparability,” such as acceding to the Lisbon Recognition Convention in 2008, beginning to investigate the introduction of a Diploma Supplement-equivalent and exploring the comparability of New Zealand's Register of Quality Assured Qualifications (New Zealand Ministry of Education and NZQA 2008, 3). New Zealand's accession to the Lisbon Recognition Convention was justified as a response to the Bologna Process, driven by the need to retain global market competitiveness. The report recommending accession notes that it "will align New Zealand with the Bologna Process and ensure that New Zealand's qualifications are better recognised and better understood by Lisbon Convention parties” (New Zealand House of Representatives, n.d.). It further explains that accession will "align New Zealand with international student market competitors.”

The Lisbon Recognition Convention requires New Zealand to encourage higher education providers to give their students a Diploma Supplement or equivalent upon graduation. It was decided to call New Zealand's Diploma Supplement-equivalent, the Tertiary Education Qualification Statement (TEQS). In 2009, guidelines for implementing a Tertiary Education Qualification Statement in New Zealand were released (NZQA 2009). However, implementation of a TEQS is not mandatory in New Zealand, remaining instead at the discretion of individual tertiary education providers. In 2010, a survey found low uptake of the TEQS (NZQA n.d.). Despite agreeing that a TEQS would benefit students and employers, most institutions were watching the implementation of the Diploma Supplement in Europe before implementing its New Zealand-equivalent, the TEQS. In 2018 uptake remains low, with only two out of four survey respondents having implemented TEQS, and with no respondent identifying the Diploma Supplement as having any bearing on internationalisation strategies.

More recent developments show that compatibility with the Bologna Process continues to receive a level of consideration in New Zealand. In 2012, NZQA changed its 
definition of a Master's degree, allowing shorter 180 point qualifications. The report accompanying this decision addressed Bologna compliance, concluding that "the proposed change to the Master's Degree definition is within the minimum length of Master's Degrees agreed within the 'Bologna process'," and that to be compatible Master's degrees can be between 180-240 New Zealand credits, which is considered equivalent to 90-120 ECTS (NZQA 2012, 5). Most recently, NZQA completed a joint project with the European Commission undertaking a comparative examination of the New Zealand Qualifications Framework (NZQF) and the European Qualifications Framework (EQF). The resulting report concluded that "while there are conceptual and functional differences between the NZQF and the EQF, due to their different purposes and functions, the analysis shows that both frameworks can be considered comparable” (NZQA and European Commission 2017, 4). The exception is NZQF level 8 (Bachelor Honours Degrees, Postgraduate Diplomas and Certificates). These have been left unlevelled to the EQF, or in other words they were not recognised as equivalent to any EQF level.

So what does this somewhat limited engagement tell us about the normative influence of Bologna? The answer returns us to the question of transformative impact: must there be an identifiable and substantive change on the part of the norm recipient for diffusion to be inferred? As highlighted earlier, for Manners $(2008,47)$ this is definitively the case, with subsequent theorists attempting to conceptualise variation in such impact. Risse's (2015) tripartite framework, for example, recognises the possibility of adoption/convergence, adaptation/transformation, or resistance. In the New Zealand case, we might add a fourth category: compliance confirmation. While, beyond perhaps acceding to the Lisbon Recognition Convention and the subsequent establishment of the TEQS, which has nevertheless failed to substantively penetrate the universities themselves, there is little evidence of a transformative impact (or indeed of resistance), it is nevertheless noteworthy 
that compatibility checks have been, and continue to be, undertaken. The perceived need for such compliance confirmation is evidence of a level of normative influence, even if substantive change is not to be found. The fact of NZQF compatibility makes it difficult to measure the influence of the Bologna Process beyond this, though perhaps the decision to leave NZQF level 8 unlevelled in relation to the EQF is indicative of an element of resistance, or at least the lack of any perception of the need for, changes to New Zealand's Qualifications Framework to bring it more closely into line with its European counterpart.

\section{The Strategic Importance of Europe}

When it comes to the strategic importance attached to Europe by New Zealand universities, the primary theme to be drawn from the survey responses is that of absence. This is particularly evident in relation to the geographic foci of internationalisation strategies, with

only two out of four respondents listing Europe among their institution's top three priority regions and both ranking it third when asked to rank regions that have been identified as geographic priorities for internationalisation. The overwhelmingly dominant focus is Asia, with all respondents ranking it as their institution's first geographic priority. When the focus shifts to which individual countries are geographic priorities, China is at the top of the list, with other Asian countries, particularly India and Malaysia, also featuring highly, as well as the United States from which there is a sizeable inflow of fee-paying study abroad students. In Europe, the United Kingdom is the clear leader, with three respondents ranking it a priority (4th, 6th, 11th). EU27 countries, where considered a geographic priority, generally fall toward the lower end of the scale. Denmark, France, Germany and Norway are the only other European countries listed (7th, 9th, 10th and 12th respectively) and none are cited by respondents at more than one institution. Meanwhile, internationalisation initiatives, which have a significant history of development in the European context, bear little influence in 
New Zealand. While there is almost universal awareness of the Bologna Process and the EHEA, ECTS, the Bologna Diploma Supplement and the Lisbon Recognition Convention, as well as Erasmus+ and Horizon2020, these frameworks are identified as having little influence in the New Zealand context, with respondents typically answering that they do not play any role in their internationalisation strategies. Exceptions were three institutions referring to the practical importance of ECTS, two institutions referring to Erasmus+ and one citing Horizon2020.

How do we explain Europe's overwhelming absence in the internationalisation strategies of New Zealand universities, especially when compared to Asia? Again, we must return to the way that internationalisation is conceived in the New Zealand context. With internationalisation largely focused on the recruitment of fee-paying international students as a way to generate revenue, Europe suffers because it is not considered a major market, certainly in comparison to Asia. In 2015/16, the total economic contribution to New Zealand of students from Europe across all education sectors was valued at NZ\$280 million, roughly equal to the total economic contribution of students from Japan alone which was NZ\$288 million (Education New Zealand 2017). By contrast, the economic contribution of students from Asia as a whole was valued at NZ\$3.14 billion, with China and India the largest contributors (NZ\$1.4 billion and NZ\$659 respectively).

Looking beyond the recruitment of international students, Europe is the most popular destination for New Zealand students who study abroad. In 2016, 1,044 New Zealand university students undertook an overseas exchange and $46 \%$ of these students went to a European country (New Zealand Ministry of Education 2018). However, promoting mobility to Europe is not a government priority. Increasing the number of students who spend a study period abroad has received recent political support, but the main focus is Asia. In 2013, the Prime Minister's Scholarships for Asia (PMSA) were launched, which provide funding for 
New Zealand higher education students to study or undertake an internship in Asia for a period of up to two years. Again, the rationale is largely economic, as articulated by the then Tertiary Education Minister, Stephen Joyce in launching the PMSA scheme, “New Zealand’s economic future is very tied in with our key trading partners in Asia... We need more young Kiwis who have had the experience of spending some time studying in Asia, and can help strengthen our people-to-people links with those countries” (Joyce 2013, para. 3). This reflects the wider policy agenda, summarised by the following statement: "Our economic future will be determined by interactions with the rest of the world - and especially the national ability to increase trade and wider economic connections with Asia... The education system will need to provide students with the required knowledge and skills” (New Zealand Government 2011, 5). For this reason, even when it comes to outbound mobility, Europe is not considered a priority, although it will be interesting to see if this changes with the recently released New Zealand International Education Strategy 2018-2030 placing emphasis on the idea of global citizenship more broadly. As a final point, and reflecting on the normative power framework outlined earlier, this Asia focus also offers a response to the question as to the material foundations for normative influence. We might, in short, infer that the EU market is insufficiently attractive to underpin significant normative transfer to New Zealand, providing support to Diez and Manners' (2007, 176) contention that “economic incentives... may underpin normative power.”

\section{Conclusion}

The analysis presented here shows that the Bologna Process has prompted action in New Zealand, although evidence of substantive normative influence is limited at best. This situation of response without transformation or resistance leads us to suggest an additional category of norm diffusion - compliance confirmation - as a way to frame the New Zealand 
case. It is perhaps most noteworthy that the response in New Zealand has been driven by economic incentives that are linked with compliance, conforming to Börzel and Risse’s (2012) concept of competition diffusion. Ensuring compatibility with the Bologna Process remains a consideration for this reason, but beyond this our analysis shows that New Zealand's internationalisation interests largely lie elsewhere, specifically Asia, driven by an institutional approach to internationalisation that is heavily focused on the recruitment of feepaying international students as a way to generate revenue and overcome domestic funding gaps. The New Zealand International Education Strategy 2018-2030 signals a government desire to move away from this model towards a broader vision of internationalisation, but it remains to be seen what impact this will have in practice. It is possible that we may see a disconnect with universities themselves, whose internationalisation strategies are likely to continue to focus on economic realities so long as current funding conditions persist.

This leaves us with a concluding question as to the generalisability of the New Zealand case. Given that the normative influence of the Bologna framework has seemingly been insufficient to outweigh the specific focus of internationalisation in the New Zealand context, what are the implications for Bologna and the EHEA elsewhere? Does normative influence firmly rest on the material foundation of an attractive European market, and are we therefore likely to see the appeal of such frameworks progressively weakened in states where, for reasons of geography or other economic, political, social or cultural factors, that market bears less apparent lustre? Certainly, the New Zealand case would suggest that in education systems characterised by entrenched neoliberal norms, the ability of European Bologna norms to penetrate may be limited, beyond prompting compliance confirmation, unless strong market incentives are present. Further studies examining such cases beyond New Zealand will be necessary to test this theory. 


\section{References}

Aggestam, Lisbeth. 2009. The World in Our Mind: Normative Power in a Multi-Polar World. In André Gerrits, ed., Normative Power Europe in a Changing World: A Discussion. The Hague: Netherlands Institute of International Relations.

Bergen Communiqué. 2005. The European Higher Education Area - Achieving the Goals: Communiqué of the Conference of European Ministers Responsible for Higher Education. Bergen, 19-20 May 2005.

Birchfield, Vicki L. 2011. The EU’s Development Policy: Empirical Evidence of 'Normative Power Europe?’. In Richard G. Whitman, ed., Normative Power Europe: Empirical and Theoretical Perspectives. Basingstoke: Palgrave Macmillan.

Bologna Declaration. 1999. The Bologna Declaration of 19 June 1999: Joint declaration of the European Ministers of Education.

Börzel, Tanka A. and Thomas Risse. 2012. From Europeanisation to Diffusion: Introduction, West European Politics 35(1): 1-19.

Bull, Hedley. 1982. Civilian Power Europe: A Contradiction in Terms?, Journal of Common Market Studies 21(2): 149-64.

De Wit, Hans and Fiona Hunter. 2015. The Future of Internationalization of Higher Education in Europe, International Higher Education, 83: 2-3.

Diez, Thomas and Ian Manners. 2007. Reflecting on normative power Europe. In Felix Berenskoetter and Michael J. Williams, eds., Power in World Politics. London: Routledge.

Duchêne, François. 1973. The European Community and the Uncertainties of Interdependence. In Max Kohnstamm and Wolfgang Hager, eds., A Nation Writ Large? Foreign Policy Problems before the European Community. Basingstoke: Macmillan. 
Education New Zealand. 2017. Economic value of international education to New Zealand 2015/16. https://intellilab.enz.govt.nz/document/42-2015-2016-economic-impact-keyfindings-infographic [accessed 16 August 2018].

European Union. 2012. Consolidated versions of the Treaty on European Union and the Treaty on the Functioning of the European Union, and Charter of Fundamental Rights of the European Union [as at 2012], Official Journal of the European Union, C 326/01.

Evans, Lewis, Arthur Grimes, Bryce Wilkinson and David Teece. 1996. Economic Reform in New Zealand 1984-95: The Pursuit of Efficiency, Journal of Economic Literature 34(4): 1856-1902.

Gerrits, André. 2009. Normative Power Europe: Introductory Observations on a Controversial Notion. In André Gerrits, ed., Normative Power Europe in a Changing World: A Discussion. The Hague: Netherlands Institute of International Relations.

Jetschke, Anja and Philomena Murray. 2012. Diffusing Regional Integration: The EU and Southeast Asia, West European Politics 35(1): 174-91.

Joyce, Steven. 2013. PM’s Scholarships for Asia announced. https://www.beehive.govt.nz/release/pm\%E2\%80\%99s-scholarships-asia-announced [accessed 15 August 2018]

Kelsey, Jane. 2000. Academic freedom: Needed now more than ever, in Rob Crozier, ed., Troubled times: Academic freedom in New Zealand. Palmerston North: Dunmore Press. Knight, Jane. 2003. Updating the Definition of Internationalization, International Higher Education 33: 2-3.

Manners, Ian. 2002. Normative Power Europe: A Contradiction in Terms?, Journal of Common Market Studies, 40(2): 235-258.

Manners, Ian. 2008. The normative ethics of the European Union, International Affairs, 84(1): 45-60. 
McCutcheon, Stuart. 2012. International students not answer to uni funding. NZ Herald, May 30. https://www.nzherald.co.nz/nz/news/article.cfm?c_id=1\&objectid=10809340 [accessed 15 August 2018].

McInnes, Craig, Peacock, Roger and Catherwood, Vince. 2006. Internationalisation in New Zealand Tertiary Education Organisations. Wellington: Ministry of Education.

New Zealand Business Roundtable (1988) Reforming tertiary education in New Zealand. Wellington: New Zealand Business Roundtable.

New Zealand Government. 2011. Leadership Statement for International Education. https://enz.govt.nz/assets/Uploads/Leadership-Statement-for-International-Education.pdf [accessed 15 August 2018]

New Zealand Government. 2018. International Education Strategy 2018-2030. https://enz.govt.nz/assets/Uploads/International-Education-Strategy-2018-2030.pdf [accessed 15 August 2018]

New Zealand House of Representatives. n.d. International treaty examination of the Convention on the Recognition of Qualifications Concerning Higher Education in the European Region (1997): Report of the Education and Science Committee. https://www.parliament.nz/resource/ennz/48DBSCH_SCR3893_1/f1b8c19bb9eeecfe40a8b12342d094f09b0ffd31 [accessed 15 August 2018]

New Zealand Ministry of Education. 2018. Tertiary Exchanges 2015 \& 2016 by Region \& Country [Internal Document]. Wellington: Ministry of Education.

New Zealand Ministry of Education and NZQA (New Zealand Qualifications Authority). 2008. New Zealand and the Bologna Process. Wellington: Ministry of Education and New Zealand Qualifications Authority. 
New Zealand Treasury. 1987. Government Management: Brief to the Incoming Government 1987, Volume II - Education Issues. Wellington: The Treasury.

NZQA (New Zealand Qualifications Authority). 2009. Guidelines for implementing a Tertiary Education Qualification Statement in New Zealand. Wellington: New Zealand Qualifications Authority.

NZQA (New Zealand Qualifications Authority). 2012. Consultation Proposal: Changing the New Zealand Master's Degree Definition. Wellington: New Zealand Qualifications Authority.

NZQA (New Zealand Qualifications Authority). n.d. Background to the Tertiary Education Qualification Statement (TEQS). https://www.nzqa.govt.nz/about-us/our-role/our-rolein-international-education/national-education-information-centre-neic/tertiaryeducation-qualification-statement-teqs/background-to-the-tertiary-educationqualification-statement-teqs/ [accessed 15 August 2018]

NZQA (New Zealand Qualifications Authority) and European Commission. 2017. Comparative Analysis of the European Qualifications Framework and the New Zealand Qualifications Framework: Joint Technical Report. Luxembourg: Publications Office of the European Union.

Olssen, Mark. 2002. The Restructuring of Tertiary Education in New Zealand: Governmentality, Neo-Liberalism, Democracy, McGill Journal of Education 37(1): 5787.

Pratt, John and Clark, Marie (2005) Penal populism in New Zealand, Punishment \& Society 7(3): 303-322.

Risse, Thomas. 2015. The Diffusion of Regionalism, Regional Institutions, Regional Governance. Paper presented to the European Union Studies Association Conference 2015, Boston, 5-7 March. 
Smith, Ian and Gilian Parata. 1997. Internationalisation of higher education in New Zealand. In Jane Knight and Hans de Wit, eds., Internationalisation of higher education in Asia Pacific countries. Amsterdam, Netherlands: European Association for International Education.

Sorbonne Declaration. 1998. Joint declaration on harmonisation of the architecture of the European higher education system by the four Ministers in charge for France, Germany, Italy and the United Kingdom in Paris on May 25.

Universities Review Committee. 1987. New Zealand's Universities: Partners in Economic Development [aka The Watts Report]. Wellington: New Zealand Vice Chancellors’ Committee.

Wilkinson, Bryce. 2017. New Zealand's Fiscal Reforms 1984-1996. Lessons from the Anglosphere No.6. Ottawa: Macdonald-Laurier Institute. 